UDC 94(477.4)«XIX»

DOI: 10.24919/2519-058x.7.131212

Mykola HALIV,

orcid 0000-0001-7068-3124

Ph D (Education), Associate Professor of Department of History of Ukraine of Ivan Franko Drohobych State Pedagogical University

(Ukraine,Drohobych) halivm@yahoo.com

\title{
THE NATIONAL POLICIES OF THE RUSSIAN \\ AND AUSTRO-HUNGARIAN EMPIRES' IN VOLHYNIA AND GALICIA (at the beginning of the XX century): A COMPARATIVE ANALYSIS
}

In the article, by means of a comparative confrontation, the national policies of the Russian and Austro-Hungarian empires in Volhynia and Galicia at the beginning of the XX century are analyzed, in particular, what concerns the three greatest ethnic groups of these lands, namely, the Ukrainians, Poles, and Jews. The territorial borders of the research under view cover the Volhynian gubernia of the Russian empire and the eastern part of Kingdom of Galicia and Lodomeria (the eastern Galicia) of Austro-Hungarian empire.

A comparative analysis of the national policy of the two aforementioned empires in concern of the three most numerous ethnic groups of Volhynia and East Galicia testifies to the presence of considerable differences in the methods of actions of the Russian and Austrian governments. The Romanovs' monarchy craved to unify the national structure of the population of the Volhynia gubernia by the assimilation of the Ukrainians, Poles, and Jews, as well as by the restriction of their economic and cultural-educational interests. The majority of the Ukrainian population of the Volhynia gubernia were treated by the Russian officials as the "little Russians", that is, as the part of the uniform Russian people. The struggle was conducted against the Ukrainian intelligentsia which supported a national-cultural separateness of the Ukrainian people. The Poles and the Jews were unequivocally treated as «foreigners» towards whom the government carried out an overtly discriminating policy. At the same time, the Habsburg monarchy, having transferred in 1860th into the parliamentarism line, recognized the national-cultural rights of the Ukrainians, Poles and Jews of Galicia. However, in a politically-administrative plane, the Austrian power relied on the Polish minority in Galicia, especially on its political, social and economic elite. In these conditions, the Ukrainians and the Jew, showing loyalty to the Austrian authorities, were actively engaged in the development of their own political, party, public, economic, and cultural institutions. In spite of all obstacles, the national policy of the two empires has something in common, namely, the problem of self-preservation as the monarchic states and an ideology of the fidelity to the monarchical house.

Key words: Volhynian gubernia, East Galicia, the Russian empire, the Austro-Hungarian empire, national policy, Ukrainians, Poles, Jews.

Микола ГАЛІВ,

кандидат педагогічних наук, доцент кафедри історії України Дрогобицького державного педагогічного університету імені Івана Франка (Україна, Дрогобич) halivm@yahoo.com

\section{НАЦІОНАЛЬНА ПОЛІТИКА РОСІЙСЬКОЇ ТА АВСТРО-УГОРСЬКОЇ ІМПЕРІЙ НА ВОЛИНІ І В ГАЛИЧИНІ (ПОЧАТОК ХХ ст.): ПОРІВНЯЛЬНИЙ АНАЛІЗ}

У статті шляхом компаративного співставлення проаналізовано національну політику Російської та Австро-Угорської імперій на Волині і в Галичині на початку ХХ ст., зокрема щодо трьох найбільших етнічних груп ичих земель: українців, поляків і євреїв. Територіальні рамки

\footnotetext{
${ }^{1}$ Публікація містить результати досліджень, проведених при грантовій підтримці Державного фонду фундаментальних досліджень за конкурсним проектом Ф77/80 - 2018 (договір від 29.03.2018)
} 
дослідження охопили Волинську губернію Російської імперії та східну частину Королівства Галичини і Лодомерії (Східну Галичину) Австро-Угорської імперії

Порівняльний аналіз національної політики двох імперій щьодо трьох найбільш чисельних етнічних груп Волині та Східної Галичини засвідчив наявність значних відмінностей у методах дій російського та австрійського урядів. Монархія Романових прагнула уніфікувати національний склад населення Волині шляхом асимілячії украӥнців, поляків та євреїв, обмеження їх економічних та культурно-освітніх інтересів. Більшість украӥнського населення Волинської губернії російськими чиновниками трактувалися як «малоросіяни», тобто частина єдиного російського народу. Боротьба велася проти української інтелігениії, яка виступала за національно-культурну окремішність украӥнського народу. Поляки та євреї однозначно трактувалися як «інородиі», щодо яких уряд проводив відверто дискриміначійну національну політику. Натомість монархія Габсбургів, ставши у 1860-х рр. на шлях парламентаризму, визнавала начіонально-культурні права українців, поляків та євреїв Галичини. Однак в політично-адміністративній площині австрійські власті спиралися на галицьку польську меншину, точніше ї̈ політичну, соціальну та господарську еліту. В иии умовах украӥнці і євреї, демонструючи лояльність до австрійських властей, активно займалися розбудовою власних політично-партійних, громадських, економічних і культурних інституцій. Попри все, національна політика двох імперій мала дещо схоже завдання самозбереження монархічних держав та ідеологію відданості монаршому дому.

Ключові слова: Волинська губернія, Східна Галичина, Російська імперія, Австро-Угорська імперія, національна політика, українці, поляки, євреї.

The statement of the problem. The study of the national policy of the imperial regimes in the West Ukrainian lands necessarily demands the use of a comparative-historical method. It gives a chance to find out the basic aspects and directions of the official policy of the Romanovs' and the Habsburg empires concerning national communities, to clarify the similar and different manifestations of the governmental-administrative influence of St Petersburg and Vienna on the motley - from ethnic viewpoint - population of the West Ukrainian lands. In particular, the use of this method is efficient in what concerns the expansion of the national movements of the Ukrainians, Poles and Jews in Volhynia and Galicia in the beginning of the XX century.

The analysis of latest researches. The national policy of the Russian empire concerning the population of Volhynia was studied by such researchers as A. Borodiy, O. Bilobrovets, O. Buravskyi, M. Barmak, M. Hauchman V. Zhelizniak, Z. Lukavskyi, V. Nadolska, I. Pohrebynska, Yu. Polishchuk, A. Ratsilevych, N. Shcherbak and others. Likewise, the policy of the Austro-Hungarian empire in the national sphere was studied by such scholars as O. Arkusha, M. Hon, M. Lytvyn, I. Monolatiy, M. Mudryi, I. Pater, Y. Honigsman, Y. Shymov, S.Shrőder, etc. Nevertheless, at present there are no such works which would clarify the national policy of the both empires in the West Ukrainian lands in a comparative manner.

The purpose of this article is to compare the national policy of the Russian and Austro-Hungarian empires in Volhynia and in Galicia $(1900-1914)$, in particular, concerning the three greatest ethnic groups of these lands, namely, the Ukrainians, the Poles, and the Jews. It should be noticed, that the territorial framework of this research covers the Volhynian gubernia of the Russian empire and the eastern part of the Kingdom of Galicia and Lodomeria (Eastern Galicia) of the Austro-Hungarian empire.

The statement of the basic material. The analysis of national structure of the population of Volhynia and Galicia in the beginning of the XX century points to the similarity in quantity indicators of the Ukrainian, Polish and Jewish communities. According to the census of 1897, which, however, specified not so much the nationality, but the native language of the listed persons, in the Volhynian gubernia there were 2095579 Ukrainian speaking population which made up $70,1 \%$ of the total gubernia's population. Then in the gubernia there 
lived 394774 Jewish speaking people that made up 13,2 \% of the gubernia population. The Poles by the quantity of their population took the third place: at that time in Volhynia, accounting 184161 Polish speakers that made 6,2\% the gubernia's total population (Pervaia vseobshchaia perepys', 1904: 3-10).

According to the census of 1900, in the whole East Galicia (excluding the Brzoziv district, which was mainly Polish by population) there lived 4735477 people. In East Galicia there were 3005916 (63,48 \%) Greek-Catholics. The number of the Roman Catholics, whom the Polish scientists rank as Poles, was 1074753 (22,70\%), the inhabitants of the Judaic religion amounted to 613764 persons (12,96 \%) (Etnohrafiia Ukrainy, 2004: 99). As can be seen, a certain difference was observed in the number of Poles in Volhynia and East Galicia, whereas the indicators of the number of the other two ethnic groups were similar.

The idea of «official nationality» was elaborated by Count S. Uvarov, minister of education and president of the St Petersburg Academy of Sciences. «Uvarov’s doctrine» was a general basis of the national policy of the Russian empire in the territory of Volhynia: Orthodoxy, autocracy, nationality. Here, as well as in other non-Russian regions, it was reduced to the ideological program of unification of the empire and cultural integration of the non-Russian peoples. The governmental activity in this region breaks up into three separate, but interconnected directions, which, however, coincided with «Uvarov's triad»: consolidation of the positions of the Orthodox church, strengthening of the state control by the full integration of the country's administrative and educational systems into one all-imperial, and an expansion of the influence of Russian education, directed into the creation a uniform Russian nationality (Haukhman, 2010: 33).

At the same time, a compromise search between the state interests in preservation of its integrity and political stability, and the aspirations of the national movements for independence in their own states, which called into question the future of Austro-Hungary, became the basic content of the political life of the Habsburg monarchy in the beginning of the XX century. E. Körber's government $(1900$ - 1904) somehow removed the international stress by suggesting to concentrate upon great economical projects. Since 1905 the government initiated a reform of the elective legislation, insisting, that the parliament should become more «democratic», than regional diets. International oppositions moved into the crown territories (including Galicia) where they - in multiple cases - became of considerable scope (Natsionalne pytannia, 2012: 77). The tradition of a formation of all-imperial patriotism and consciousnesses («Austrian loyalty») in the national regions of the Danube empire, to a certain extant, promoted the revival of national consciousness of the Ukrainians, Poles, and Jews. As I. Monolatiy remarked, the ethnic-national management of the ruling dynasty and local authorities in the West Ukrainian region was carried out on the bases of the state paternalism, and the ethnic communities here did not oppose it: after all, their leaders conducted the dialogue, which was different both by quality and political expediency. In such a way the «cooperation with Vienna» was being constructed, which gave the chance to defend their own national-political ideals (Monolatiy, 2008a: 164).

The policy of the aforementioned empires concerning the Ukrainians, Poles and Jews deserves considering in more details.

The Ukrainians. The official policy of the imperial government concerning vast masses of Ukrainians (then «Little Russians») was not discriminational. Officially, the Ukrainians were considered but Russians and were given possibilities to do any career provided that they knew the Russian language and confess Orthodoxy. The Russian officials put a special 
accent on the schooling process. In the Russian empire the school policy intertwined with the national one which main task consisted in a gradual merge of the national outskirts into a uniform state by means of denationalization and the forceful policy of Russification. Notwithstanding that, in Volhynia the quantity of elementary schools was but very small and, no wonder, that illiteracy became a usual phenomenon among Ukrainians. But that prevented the realization of the Russification policy through school. What is interesting, is that the Volhynian governors did not care for the distribution of schooling as they did not see any threat from the Ukrainians whom they considered only as a component of the Russian people. In general, the anti-Ukrainian prohibitions of 1863 and 1876 were directed mainly not against the Ukrainian population as such, but against the Ukrainian intelligentsia, that is, against the Ukrainian national creation as most of the population of the Volhynia gubernia was illiterate, and the prohibitions concerned just writing (Zhelizniak, 2016: 28). It is by this fact that the struggle against the Ukrainian national movement after the Russian revolution of 1905 1907 can be well explained. As is known, during the revolution in Volhynia some cells of the Prosvita society were formed, however, until 1912, under the pressure of P. Stolypin's reactionary policy, all of them stopped their activity. Contrary to the Ukrainian political parties, which actively operated in Volhynia (in particular, the Revolutionary Ukrainian party), the imperial power supported the Russian chauvinistic organizations, including «the Union of the Russian people» (Ratsilevych, 2004: 70).

The policy of the Habsburg monarchy in Galicia concerning the Ukrainians considerably differed from the policy of the Romanovs' empire. The Austrian government recognized the singularity of the Ukrainian people and from the second half of the XIX century refused from its plans of Germanization. However, after 1867 the governmental policy concerning the Ukrainians in Galicia gained a specific character on account of the tolerability of the Polish political and cultural domination in the region. The Ukrainians were discharged of the power bodies in the lands where the key administrative places were occupied by the Poles. Under those conditions they initiated a struggle for national equality. It is necessary to take into consideration that in the beginning of the XX century there were already several Ukrainian political parties, among which the Ukrainian national-democratic party got the largest distribution.

The Austrian political regime gave possibilities to the Ukrainians to combat for the language issue. Contrary to the accurate instructions which made the official bodies to answer to the references in what language they were written, the local authorities often communicated with the Ukrainian parties in Polish either «by principle» or through an oversight or ignorance. The Ukrainians led the struggle for the real and not the nominal right to use their Ukrainian language in administration and courts. In the beginning of the XX century there was a movement of the Ukrainian rural communities for the change of the official language from Polish to Ukrainian. The action of Greek-Catholic priests who sent back the Polish language official requirements concerning registers of births in the record books gained a mass character. Particularly sharp was the struggle for school training. In almost all the elementary schools in cities and in the majority of secondary schools the working language was Polish (except for the Ukrainian academic gymnasium in Lviv, and the German gymnasiums in Lviv and Brody). At the break of the XIX - XX centuries the Ukrainians had a success with the opening of the Ukrainian state gymnasium in Peremyshl (1895), Kolomyia (1900), Ternopil (1901), and Stanislaviv (1905). Further on, as the openings of the Ukrainian state gymnasiums were blocked by the Polish majority in the Galician diet, therefore the Ukrainians took to the establishment of private gymnasiums (Natsionalne pytannia, 2012: 79-80). 
A number of educational institutions, as the teacher training seminary and Lviv university, legally were bilingual. However, in teacher training seminaries only minor subjects were taught in the Ukrainian language. At Lviv university the overwhelming majority of chairs was in the hands of the Poles; the Polish language was used in the internal administration and office-work, contrary to the fact that the Ukrainian students were a weighty numerical group. In 1913/14 the Poles made up 44,6\% of the students of Lviv university, the Ukrainians made up $25,9 \%$, and the Jews accounted $28,1 \%$. At the university 80 Polish and 8 Ukrainian chairs operated. From the beginning of the XX century of the creation of a Ukrainian university in Lviv became a key requirements of the Ukrainians. It caused much opposition on behalf of the Polish politicians who were afraid that a Ukrainian university would serve as the tool of «Ukrainization» of Lviv. Nevertheless, in the end of 1912 the Austrian government did process over the project of the establishment of a Ukrainian university in Galicia not later than 1916, however, it was not realized (Natsionalne pytannia, 2012: 80).

The Poles. In Volhynia the Poles represented an overwhelming majority of szlachta, that is, the nobility of the country. After the Polish rebellion of $1831-1833$ and 1863 the Russian power liquidated the achievements of the Polish cultural-educational activity in Volhynia. The process of liquidation of Polish school training begun, although it remained only at the private level. It was forbidden for Roman-Catholic clergy to open schools, to instruct and teach children of elementary education level in the Polish language. A supervision over those Poles who tried to teach children reading and writing in the Polish language was established. The printing, sale and use of the Polish books ad newspapers on the whole territory was forbidden. The struggle against penetration into Ukraine of the products of the Polish press and the communication with the Polish emigrants was conducted. The imperial government tried to undermine also the economical potential of the Polish minority, first of all, that of szlachta. As early as in 1865 the decree about the prohibition for the Poles to buy new lands had been issued, which was valid till 1905 (Buravskyi, 2004: 38, 40; Polishchuk, 2012: 145-150, 208-217; Shcherbak, 2005: 239).

In the year of the Russian revolution a pressure upon the Poles nearly stopped. Poles had an opportunity to take part in elections into the State Duma. However, election campaigns had its special characteristic features in Volhynia. Here a complicated electoral system was introduced, which did not give chances to the Poles to make their way to the Russian parliament (Łukawski, 1967: 16). All in all, to the first State Duma only three persons were elected from Volhynia (Kwiatkowski, 1932: 153). However, in the following elections the Poles were actively counteracted by Russian chauvinists, in particular, by members of the "Pochaiv Union of the Russian people" (Bilobrovets, 2014: 19). In general, historians name the policy of the Russian empire concerning the Poles as «the policy of de-Polonization» (Nadolska, 2003: 48-55).

An entirely other policy concerning the Poles in Galicia was maintained by the Habsburg monarchy. After Galicia was granted an autonomy (1867), the Austrian government, in fact, agreed with the Polish domination in the region, having received instead a partnership of the Poles in formation of the majority in the Austrian parliament. «A special status» of the region was fixed by the creation in 1871 of the post of the so-called minister without a portfolio (the minister for the region) which played a role of the intermediary between the Austrian and the regional governments and, informally, also prevented the direct contacts between Vienna and the Ukrainian politicians. The posts of the minister, Galician viceregent, and marshal of the Galician diet were, as a rule, held by the Polish aristocrats (Natsionalne pytannia, 2012: 78-79). 
The Poles of the Austrian Galicia were as if a semi-latent «dominating people», which, though deprived of their own independent state, preserved its traditional elite and domination zones. Under the condition of the Polish nobility's domination the autonomy of Galicia automatically meant the Polish autonomy. Thanks to their actual domination in the region the Polish officials restored their monopoly position in the bodies of the regional power and local government (Monolatii, 2008a: 161). By national structure the Galician officials were mostly either Polish or Polonized. For a Ukrainian to chose an official career almost inevitably meant his Polonization. The regional school council which consisted mainly of Poles, quickly enough carried out the Polonization of Galicia (Natsionalne pytannia, 2012: 79). Such a policy gave grounds to the Polish political leaders during the First World War to set the goal of restoration of the independent Polish state.

The Jews. The policy concerning the Jews in the Russian empire was of restrictive character and was directed for the prevention of their penetration into the Great Russian gubernias in order to concentrate them mainly in the western regions of the empire, which list included also the Volhynian gubernia. Still in 1791 Queen Catherine II by her decree established the territorial borders of the constant residing of the Jews, - «a strip of constant settlement». The strip was abolished only in 1917 after the February revolution by the law «On cancellation of confessional and national restrictions» (Barmak, 1999: 116, 121). In 1882 it was forbidden for the Jews to live in villages even within the borders of «strips of settlement» (Pohrebynska).

Except territorial restrictions, the Jews were under pressure in the economic, religious, and educational aspects. In 1864 the decrees were issued that forbade all the Jews without exception acquisitions of land from landowners and peasants by any way in nine western gubernias, that is, in the gubernias of «the strips of constant settlement». On July 23rd, 1865 the "Instruction on the order of sale of state lands in the western gubernias" was accepted. The Jews, as well as the Poles, were excluded from the list of subjects of the purchase of manors. According to the law, from December $8^{\text {th }}, 1867$ the Jews could become tenants or managing directors of mills, sugar, glass and other factories, the management of which required technical knowledge and some available capital (Borodii, 2014: 76). Within the borders of the «strip of settlement», as well as in certain other places where a constant stay was authorized for certain categories of the Jewish population, the Jews had the right to buy real estate. But this general rule was limited by numerous restrictions. Within the «strip of settlement», outside of cities and small towns, since 1882 the conclusion of saling, pawning, and lease agreements addressed to Jews was suspended. In the western gubernias the Jews were not authorized to be also shareholders of sugar factories. Eventually, in the fifty versts wide border land the Jews were not authorized to possess real estates (Pohrebynska).

In the XIX century in Russia a special system of the raised taxation of the Jews was valid. Since 1884, a «box tax» from the Jews was introduced. It existed in two forms, - general and auxiliary. The former was the tax on the consumption of meat by the Jews. It was collected from each animal killed for the kosher meal, from each killed bird, and from the sale of each pound of kosher meat. The auxiliary tax was the one on the inherited by the Jews property or their industrial enterprises, on the incomes from the tenancy of shops, barns, and housing premises, which belonged to them. Those taxes were also on the use of the Jewish clothes, both used by men and women. From 1844 the candle tax began to be collected on the kindling of candles during Jewish meetings on Saturdays. Only by this tax the Jews had to pay annually nearly 230000 rubles. A special tax was imposed on the Jewish printing houses. 
Since 1862 the Jews were permitted to print Jewish books, but there was an established payment for each printing press (Pohrebynska).

In the beginning of the XX century the Russian tsarism policy concerning the Jews was formulated frankly enough: either their assimilation and obedience to the nation-wide purposes of Russia, or emigration. The whole system of legislative regulation of life and activity of the Jews driven into the «stripe of settlement» was directed to forcing them to reject their national and religious traditions and ,eventually, to make a heavy personal choice within the limits of the cruel internal alternative as formulated by the imperial politicians (Pohrebynska).

The policy of the Austro-Hungarian empire concerning the Jews was entirely different. It should be noticed, that the Jewish population of Galicia was congregated into 262 religious communities which had 250 synagogues and 376 schools. By the part of the Jewish population Galicia was ahead of all other gubernias of the Habsburg monarchy. In $190066,2 \%$ of Jews of Austria lived in Galicia. In 1910 61,6 \% of the Jewish population in Eastern Galicia lived in cities and small towns, making in some of them an overwhelming majority. The largest Jewish communities lived in Lviv, Kolomyia, Brody, Ternopil, Stanislaviv, Peremys$\mathrm{hl}$, Drohobych, and Stryi. In a number of professional groups the percentage of the Jewish population was very high. So, by the data for 1900 , the Jews made up almost $40 \%$ of those occupied in industry, $74 \%$ in trade, $27 \%$ in public service, and $49,3 \%$ of all the Galician intelligentsia. The concentration in the hands of the Jews of the landed property, rent of agricultural lands had a tendency to increasing (Natsionalne pytannia, 2012: 85). The Austrian government should have accounted for the influence of the Jews in social and economic life of the land.

In spite of all, the Austrian power wanted to stop the practice of the separation of the Jews from the rest of the society and to make usual subordinated citizens of them. Granting the Jewish communities the right to self-management, the Austrian government officials put them under the state control, having introduced, in particular, the post of «the regional rabbi», - the nominal head of all the Jewish communities (kagals). The constitutional reforms of 1867 and 1905 opened wide opportunities of political emancipation for the Jews: the leveling of civil rights put an end to the appreciable aspiration of the Christian communities in that period to limit the public activity of the Jews. The new legal field allowed the Jews an access, first of all, to the city and district councils. The gaining of equality initiated a difficult period of modernization of the Jewish community in the land, which had to learn to live «outside the Ghetto», in a wider political and cultural contacts with the external world. The modernization processes passed at the background of discussions in Jewish communities. In a rivalry of the orthodox with the reformers the advantage of the latter became clear, but, at the same time, their movement was accompanied by assimilating processes. Two assimilatory directions were formed, respectively, to the «high» German (its adherents asserted that the Jews owe their freedom and equality to the Habsburgs) and Polish (the Jews should be grateful to the Poles for their merits in history) cultures (Natsionalne pytannia, 2012: 85-86).

At the same time, being Austrian citizens equal in rights, the Jews were deprived of the rights of a national community. The Polish elite, which was stronger in the political-economical domain, used the union with the Jews as a tool of the national oppression of the Ukrainian population. The outstanding Jewish representative V. Zhabotynskyi in 1906 wrote the following on this issue: «In the whole Polish hegemony in Galicia the Jewish help played an outstanding role. The falsification of the census «enlisted» all the Jewry in the land to be of Polish nationality... And the loss of this «augment» will mean the end of the legend about 
the Polish majority and the beginning of the end of a reactionary szlachta domination. Best of all the Poles themselves feel it, and it is from there that their rage comes with which they pursue the Jewish «separatism»»" (Monolatiy, 2008b: 157). Also characteristic of the position of the Jews in Galicia was the active Zionist and Jewish social democratic movements, and the activity of some parties (in particular, the Jewish national party of Galicia, founded in 1893) and professional, youth and cultural-educational public organizations (Monolatiy, 2008b: 164-166). All that prepared the national Renaissance of the Jews of Galicia at the beginning of the XX century.

The conclusions. Thus, a comparative analysis of the national policy of the Russian and Austro-Hungarian empires concerning three most numeral ethnic groups of Volhynia and Eastern Galicia has certified the presence of considerable differences in the methods of government of the two states. The Romanovs' monarchy aspired to unify the national structure of the population of Volhynia by the assimilation of the Ukrainians, Poles and Jews, restriction of their economic and cultural-educational interests. The majority of the Ukrainian population of the Volhynian gubernia were treated by Russian officials as «Little Russians», that is, like a part of the uniform Russian people. The struggle was conducted against the Ukrainian intelligentsia who supported the national-cultural separateness of the Ukrainian people. The Poles and the Jews were unequivocally treated as foreigners concerning whom the government carried out a frankly discriminational national policy. On the contrary, the Habsburg monarchy, having become parliamentary in 1860, recognized the national-cultural rights of the Ukrainians, Poles and Jews of Galicia. However, in a politically-administrative aspect the Austrian authorities more relied on the Galician Polish minority, more precisely, on its political, social and economic elite. Under these conditions the Ukrainians and the Jew, showing loyalty to the Austrian authorities, were actively engaged in the development of their own political-party, public, economic and cultural establishments. Eventually, the national policy of the both empires had one in common, that was the problem of self-preservation of the monarchic states and the ideology of fidelity to the monarchical dynasty.

\section{BIBLIOGRAPHY}

Бармак, 1999 - Бармак М. Німецьке, чеське та єврейське населення Волинської губернії (1796 - 1914 рр.). Тернопіль: ТДПУ, 1999. 208 с.

Білобровець, 2014 - Білобровець О.М. Вибори до Державної думи та Державної ради на Правобережжі: участь польського населення // Наукові записки Вінницького державного педагогічного університету імені Михайла Коцюбинського. Серія: Історія. 2014. Вип. 22. С. 17-20.

Бородій, 2014 - Бородій А. Свреї в аграрних відносинах на території Правобережної України у 1861 - 1914 рр.: дис. ...канд.іст.наук: 07.00.01. Кам’янець-Подільський, 2014. 258 с.

Буравський, 2004 - Буравський О. А. Поляки Волині у другій половині XIX - на початку ХХ ст. Житомир: Вид-во ЖДУ, 2004. 168 с.

Гаухман, 2010 - Гаухман М. Російська національна політика щодо польського питання на Правобережній Україні (1905 - 1914 рр.) // Волинські історичні записки: збірник наукових праць. 2010. T. 5. C. 32-37.

Етнографія України, 2004 - Етнографія України: Навч. посібник / За ред. С. Макарчука. Львів: Світ, 2004. 520 с.

Желізняк, 2016 - Желізняк В. Національна політика Російської імперії на Волині: управлінський аспект // Наукові записки Тернопільського національного педагогічного університету імені Володимира Гнатюка. Серія: Історія. 2016. Вип. 2(1). С. 25-29.

Монолатій, 2008a - Монолатій І. С. Австролоялізм як «тактика очікування» етнонаціональних спільнот західноукраїнського регіону // Наукові записки Інституту політичних і етнонаціональних досліджень ім. І. Ф. Кураса НАН України. 2008. Вип. 41. С. 156-166. 
Монолатій, 2008b - Монолатій І. Євреї у Галичині в австрійський період (1772 - 1918 pp.) // Незалежний культурологічний часопис «І». 2008. № 51. С. 150-169.

Надольська, 2003 - Надольська В. В. Політика деполонізації в Російській імперії: витоки, шляхи реалізації, наслідки // Наукові записки національного університету «Острозька академія». Серія. Історичні науки. Острог, 2003. С. 48-55.

Національне питання, 2012 - Національне питання в Україні XX - на початку XXI ст.: історичні нариси / [авт. кол.: О. Г. Аркуша, В. Ф. Верстюк та ін.; відп. ред. В. А. Смолій]. Київ: Ніка-Центр, 2012. 590 с.

Первая всеобщая перепись, 1904 - Первая всеобщая перепись населения Российской империи 1897 г. Волынская губерния / ред. Н. А. Тройницкий. СПб.: Издание центрального статистического комитета Министерства внутренних дел, 1904. Т. VIII. 280 с.

Погребинська - Погребинська І. Законодавство Російської імперії щодо євреїв. У складі двох імперій (кінець XVIII ст. - початок XX ст.) // Єврейська енциклопедія - Розділ II. URL http://holocaust-ukraine.net/ru/razdel_ii.htm

Поліщук, 2012 - Поліщук Ю. М. Національні меншини Правобережжя України у контексті етнічної політики Російської імперії (кінець XVIII - початок XX ст.). Київ: IПіЕНД ім. І. Ф. Кураса НАН України, 2012. 432 с.

Рацілевич, 2004 - Рацілевич А. П. Особливості українського національного руху на Волині початку XX ст. // Ucrainica Polonica. Київ-Житомир, 2004. Т. 1. С. 67-76.

Щербак, 2005 - Щербак Н. О. Національне питання в політиці царизму у Правобережній Україні (кінець XVIII - початок XX століття). Київ: Ризографіка, 2005. 616 с.

Łukawski, 1967 - Łukawski Z. Koło polskie w Rosyjskiej Dumie Państwowej w łatach 1906 1909 [Polish faction in the Russian parliament in the years 1906 - 1909]. Wrocław, 1967. $229 \mathrm{~s}$.

Kwiatkowski, 1932 - Kwiatkowski W. Walka o wolność i potęgę Polski [The fight for the freedom and power of Poland]. Lwów, 1932. T. 1. 369 s.

\section{REFERENCES}

Barmak, 1999 - Barmak M. Nimetske, cheske ta yevreiske naselennia Volynskoi hubernii (1796 - 1914 rr.) [German, Czech and Jewish population of Volhynian gubernia (1796 - 1914)]. Ternopil: TDPU, 1999. 208 p. [in Ukrainian]

Bilobrovets, 2014 - Bilobrovets O. M. Vybory do Derzhavnoi dumy ta Derzhavnoi rady na Pravoberezhzhi: uchast polskoho naselennia [Elections to the State Duma and the State Council on the Right-Bank Ukraine: participation of the Polish population]. Naukovi zapysky Vinnytskoho derzhavnoho pedahohichnoho universytetu imeni Mykhaila Kotsiubynskoho. Seriia: Istoriia. 2014. Vyp. 22. Pp. 17-20. [in Ukrainian]

Borodii, 2014 - Borodii A. Yevrei v ahrarnykh vidnosynakh na terytorii Pravoberezhnoi Ukrainy u $1861-1914$ rr. [Jews in agrarian relations in the territory of the Right-Bank Ukraine in 1861-1914]: dys. ...kand.ist.nauk: 07.00.01. Kamianets-Podilskyi, 2014. 258 p. [in Ukrainian]

Buravskyi, 2004 - Buravskyi O. A. Poliaky Volyni u druhii polovyni XIX - na pochatku $\mathrm{XX}$ st. [Poles in Volhynia in the second half of the nineteenth and early twentieth centuries]. Zhytomyr: Vyd-vo ZhDU, 2004. 168 p. [in Ukrainian]

Haukhman, 2010 - Haukhman M. Rosiiska natsionalna polityka shchodo polskoho pytannia na Pravoberezhnii Ukraini (1905 - 1914 rr.) [Russian national policy on the Polish question in the RightBank Ukraine (1905 - 1914)]. Volynski istorychni zapysky: zbirnyk naukovykh prats. 2010. T. 5. Pp. 32-37. [in Ukrainian]

Etnohrafiia Ukrainy, 2004 - Etnohrafiia Ukrainy [Ethnography of Ukraine]: Navch. posibnyk / Za red. S. Makarchuka. Lviv: Svit, 2004. 520 p. [in Ukrainian]

Zhelizniak, 2016 - Zhelizniak V. Natsionalna polityka Rosiiskoi imperii na Volyni: upravlinskyi aspekt [The national policy of the Russian Empire in Volhynia: a managerial aspect]. Naukovi zapysky Ternopilskoho natsionalnoho pedahohichnoho universytetu imeni Volodymyra Hnatiuka. Seriia: Istoriia. 2016. Vyp. 2(1). Pp. 25-29. [in Ukrainian]

Monolatiy, 2008a - Monolatiy I.S. Avstroloializm yak «taktyka ochikuvannia» etnonatsionalnykh spilnot zakhidnoukrainskoho regionu [An Austrian loyalty as a «tactic of expectation» of ethnonational 
communities of the Western Ukrainian region]. Naukovi zapysky Instytutu politychnykh i etnonatsionalnykh doslidzhen im. I. F. Kurasa NAN Ukrainy. 2008. Vyp. 41. Pp. 156-166. [in Ukrainian]

Monolatiy, 2008b - Monolatiy I. Yevrei u Halychyni v avstriiskyi period (1772 - $1918 \mathrm{rr}$.) [Jews in Galicia during the Austrian period (1772 - 1918)]. Nezalezhnyi kulturolohichnyi chasopys «I». 2008. № 51. Pp. 150-169. [in Ukrainian]

Nadolska, 2003 - Nadolska V. V. Polityka depolonizatsii v Rosiiskii imperii: vytoky, shliakhy realizatsii, naslidky [The policy of de-polonization in the Russian empire: origins, ways of realization, consequences]. Naukovi zapysky natsionalnoho universytetu «Ostrozka akademiia». Seriia. Istorychni nauky. Ostroh, 2003. Pp. 48-55. [in Ukrainian]

Natsionalne pytannia, 2012 - Natsionalne pytannia v Ukraini XX - na pochatku XXI st.: istorychni narysy [The national question in Ukraine XX - early XXI century: historical essays]. Avt. kol.: O. H. Arkusha, V. F. Verstiuk ta in.; vidp. red. V. A. Smolii. Kyiv: Nika-Tsentr, 2012. 590 p. [in Ukrainian]

Pervaia vseobshchaia perepys', 1904 - Pervaia vseobshchaia perepys' naselenyia Rossyiskoy imperiy $1897 \mathrm{~h}$. Volynskaia hubernyia [The first general census of the population of the Russian Empire in 1897. Volyn province]. Red. N. A. Troinitskiy. SPb.: Izdanie tsentralnoho statisticheskoho komiteta Ministerstva vnutrennikh del, 1904. T. VIII. 280 p. [in Russian]

Pohrebynska - Pohrebynska I. Zakonodavstvo Rosiiskoi imperii shchodo yevreiv. U skladi dvokh imperii. Yevreiska entsyklopediia - Rozdil II (kinets XVIII st. - pochatok XX st.) [The Russian Empire's legislation about Jews. In the composition of two empires (the end of the XVIII century - the beginning of XX century). Jewish Encyclopedia - Chapter II]. URL - http://holocaust-ukraine.net/ru/ razdel_ii.htm [in Ukrainian]

Polishchuk, 2012 - Polishchuk Yu. M. Natsionalni menshyny Pravoberezhzhia Ukrainy u konteksti etnichnoi polityky Rosiiskoi imperii (kinets XVIII - pochatok XX st.) [National Minorities of the Right-Bank Ukraine in the context of the Russian Empire's ethnic policy (the end of the XVIII - the beginning of the XX century)]. Kyiv: IPiEND im. I.F. Kurasa NAN Ukrainy, 2012. 432 p. [in Ukrainian]

Ratsilevych, 2004 - Ratsilevych A. P. Osoblyvosti ukrainskoho natsionalnoho rukhu na Volyni pochatku XX st. [The features of the Ukrainian national movement in Volyn at the beginning of the XX century]. Ucrainica Polonica. Kyiv-Zhytomyr, 2004. T. 1. Pp. 67-76. [in Ukrainian]

Shcherbak, 2005 - Shcherbak N. O. Natsionalne pytannia v politytsi tsaryzmu u Pravoberezhnii Ukraini (kinets XVIII - pochatok XX stolittia) [Ther national question in the Russian Empire's policy in the Right-Bank Ukraine (the end of the XVIII - the beginning of XX century)]. Kyiv: Ryzohrafika, 2005. 616 p. [in Ukrainian]

Łukawski, 1967 - Łukawski Z. Koło polskie w Rosyjskiej Dumie Państwowej w łatach 1906 1909 [The Polish milieu in the Russian People's Duma in 1906 - 1909]. Wrocław, 1967. 229 p. [in Polish]

Kwiatkowski, 1932 - Kwiatkowski W. Walka o wolność i potęgę Polski [The struggle for Poland's liberation and power]. Lwów, 1932. T. 1. 369 p. [in Polish]

Стаття надійшла до редакиіï 19.04.2018 p. 